\title{
Matrimônio e Dote: alicerces sociais de uma elite de Antigo Regime
}

Marriage and Dowry: social foundations of an old regime elite

Débora Cristina Alves*

dediliber@yahoo.com.br

Resumo: O presente artigo tem como objetivo analisar as diferentes estratégias matrimoniais e de concessão de dotes empregadas pela elite da região de Guarapiranga (MG), entre 1715 e 1790 , com a finalidade de se ascender social, econômica e politicamente. Próximo ao efervescente núcleo minerador da freguesia de Nossa Senhora da Conceição de Guarapiranga, seus habitantes aproveitavam da possibilidade de angariar prestígio e sucesso econômico através da exploração aurífera, além da agricultura e pecuária, sem desatender o estabelecimento de um bom laço matrimonial.

Palavras-chave: dote, alianças matrimoniais, redes familiares

Abstract: This article aims to analyze the different marriage strategies practiced by the elite on Guarapiranga region (MG), between 1715 and 1790, in order to ascend socially, economically and politically. Near the bustling mining center of Nossa Senhora da Conceição de Guarapiranga, its inhabitants took advantage of the opportunity to raise prestige and economic success by gold mining, in addition to agriculture and livestock, without neglecting the establishment of a good marriage bond.

Keywords: dowry, marriage alliances, family networks

*Mestre e doutoranda em História Social pela Universidade Federal de Juiz de Fora (MG). 


\section{Introdução}

O trabalho baseia-se em inventários postmortem, testamentos e processos matrimoniais da região de Guarapiranga (MG) entre período de 1715 a 1790. Os inventários arrolam detalhadamente os bens, objetos e ativos e passivos financeiros do indivíduo e da sua família e representam uma janela privilegiada para a realidade da vida material e cotidiana dos homens e mulheres do período colonial. Os processos matrimoniais, por sua vez, são fontes riquíssimas em que se encontram dados, como a data dos casamentos, a origem dos nubentes, a trajetória dos mesmos até o momento da realização da cerimônia e as razões que poderiam impedir a união do casal e se encontram no Arquivo Eclesiástico da Arquidiocese de Mariana.

Para nossa análise utilizamos 149 inventários que estão presentes nos cartórios do $1^{\circ}$. e $2^{\circ}$. Ofício da Casa Setecentista de Mariana e no Fórum de Piranga. Entre eles 77 continham testamentos em seu arrolamento. Durante a pesquisa analisamos as famílias da região e suas relações entre seus pares, especificando a relevância do dote como partícipe da divisão de heranças não igualitária característica de uma sociedade pautada nos preceitos de Antigo Regime, hierarquizada e excludente. A princípio empregamos o método de reconstituição de paróquias através de indicações nominativas, desenvolvido pelo NEPS da Universidade do Minho (AMORIM; DURÃES; FERREIRA, 2003), no qual se define como unidade de análise o indivíduo e seus encadeamentos genealógicos, permitindo iluminar os ciclos familiares e servindo, assim, não apenas a fins de análise demográfica, mas também de história social (AMORIM; DURÃES; FERREIRA, 2003).

Para pesquisa focalizamos a análise das famílias que consideramos de "elite", estas seriam apenas as que possuíam um monte-mor superior a $5.000 \$ 000$ réis e bens como fazenda e escravos, portanto, denominamos nossa elite como "econômica". Dentre estas apenas 22 conferiram dotes às suas filhas em vias de contrair matrimônio. Portanto, foram os matrimônios realizados por essas famílias e as estratégias empregadas por estes indivíduos para obtenção de prestígio e distinção social que nossa análise evidencia.

Fundamentamos nossa pesquisa para análise da sociedade colonial nos preceitos do Antigo Regime nos Trópicos, no qual define a sociedade como um sistema em que os indivíduos estariam imersos em relações pactadas, de arranjos e trocas constantes. Assinalada pelos atos de graça, os indivíduos criavam deveres quase-jurídicos; a graça do rei, mas também de particulares, cunhava uma rede pactos, de expectativas e de quase direitos que organizava tal sociedade (HESPANHA, 2007, p. 48).

Essa "negociação" aponta que se de um lado a coroa usufruía dos recursos financeiros e contribuições políticas advindos das áreas coloniais, por outro, destaca que vários grupos de indivíduos dependiam de igual forma da coroa que lhe conferia "reconhecimento" e "aval institucional" necessários para a manutenção de suas posições sociais diante da sociedade local onde pertenciam (GOUVEA; FRAGOSO, 2010). Os grupos eram, portanto, formados por membros de uma elite local que "negociava" a participação e autonomia nesse ínterim social. Essas negociações não eram apenas parte do seio econômico e político da sociedade, no âmbito social e familiar elas eram determinantes e constituíram importantes laços entre as principais famílias de elite.

Os regulamentos expressos nas Ordenações de Portugal estabeleciam que o sistema de heranças tanto nas possessões ultramarinas quanto no reino deveriam seguir o padrão igualitário entre todos os filhos (DURÃES, 2004, p. 15). No entanto, através da análise dos inventários e testamentos percebemos que a região 
de Guarapiranga, assim como outras regiões brasileiras possuía um sistema não igualitário de heranças, expresso de forma contundente na dotação das filhas em vias de contrair matrimônio.

Ao dotar suas filhas com bens que superaram, muitas vezes, a legítima a ser posteriormente recebia conferia a essas mulheres a possibilidade de obter promissores casamentos e as privilegiavam em detrimento dos irmãos. Os cônjuges, em sua maioria, foram portugueses ou parentes próximos que consolidaram trocas matrimoniais vantajosas de ampliação ou manutenção de "status" e fortuna.

Neste sentido, procuramos compreender de que forma os matrimônios e dotes auxiliaram as famílias e indivíduos em seu projeto de ascensão social e econômica, preceitos determinantes em uma sociedade marcadamente hierarquizada e excludente de Antigo Regime.

\section{Matrimônios e sua influência no seio familiar}

A importância do matrimônio e as leis que regiam esse sacramento foram estabelecidas no Concílio de Trento em 1563, no qual se produziu o documento intitulado "Doutrina do Sacramento do Matrimônio", que definia regras básicas para que o casamento fosse realizado. Entre os cânones registrados estavam à condenação a poligamia, o casamento de eclesiásticos, o poder de dissolver e proibir um novo casamento, de estabelecer impedimentos por parentesco de consanguinidade, de afinidade e espiritual e determinou o que seria considerado adultério ou concubinato (MACHADO, 2008, p. 142).

Nessas mesmas Constituições, a Igreja procurou ampliar sua influência e determinou os caminhos para coibir as uniões sucessivas e regulou às práticas matrimoniais costumeiras, como o casamento clandestino ou de juras, impelindo-as para o âmbito da Igreja. O que se sabe é que independente do interesse moral, doutrinal e teológico, as leis da Igreja também estariam diretamente ligadas aos interesses políticos e econômicos que girava em torno do casamento (MACHADO, 2008, p. 142).

De acordo com as doutrinas católicas para que uma união sacramental fosse realizada era preciso uma inspeção rigorosa por parte da Igreja, que examinava a vida dos cônjuges e determinava diversos componentes que impediriam o casamento, como o de consanguinidade e de parentesco.

Neste sentido, o casamento assumia um caráter sagrado, em que o profano e a transgressão não atingiriam o seio santificado da família e do lar. A casa seria então uma entidade unificada dotada de uma existência duradoura e temporal (SCOTT, 1999, p.168). Assim:

[...] o casamento não só resultava de um
ato voluntário por parte dos nubentes (ou
de alguém por parte deles), como tam-
bém se traduziu na criação de uma nova
célula do organismo social. Seja porque
dá origem à criação de uma nova uni-
dade doméstica, seja porque se traduz no
prolongamento de uma linhagem ou de
uma "casa" preexistente (SCOTT,
1999, p. 168).

O princípio básico que norteava a realização de um casamento era o de igualdade - igualdade etária, social, física e moral. De acordo com os textos moralistas do período era preciso que os indivíduos: "Casem primeiro as idades, as condições, as saúdes e as qualidades, e então casarão bem as pessoas" (SILVA, 1984, p. 66). Assim, o preceito de igualdade social estabelecido pelas normas Católicas determinava que livres deveriam se casar com livres, preto-forros com pretoforros, cativos com cativos e pardos livres com seus semelhantes. Como nossa análise está fundamentada em um grupo específico, o de elite, o preceito de igual- 
dade social foi seguido com rigor todos os casamentos pesquisados foram realizados entre livres.

Diferentemente da sociedade contemporânea, em uma sociedade de Antigo Regime, o lugar social não passava exclusivamente pela posse de bens econômicos, mas antes pela demarcação da diferença de condição em relação aos demais indivíduos. Na América Portuguesa, considerando a existência da escravidão, todo homem livre, principalmente se fosse branco, já era a priori um indivíduo em condição de superioridade diante de muitos outros (ALMEIDA, 2007, p. 130).

No entanto, o preceito de igualdade etária nem sempre foi condição precisa para a realização de um casamento. A diferença de idade entre homens e mulheres era comum, e as esposas muitas vezes tinham idade muito inferior a seus maridos. Como o caso de Antônio Alves Ferreira, viúvo em Portugal, que ao se estabelecer nas Minas, casa-se aos 40 anos com Ana Cabral Câmara de apenas 15 anos. ${ }^{1}$ A idade média dos indivíduos ao se casarem, em sua maioria, foi superior a de suas contraentes, já que foi habitual a estes homens, principalmente portugueses, fixar-se primeiro na região, agregar riqueza e posteriormente contrair esponsais com alguma nativa de importante família (ALMEIDA, 2010).

Os matrimônios mais do que acordos eram negócios, em que os genitores estrategicamente "arranjavam" os cônjuges de seus filhos e filhas no intuito preciso de ampliar ou manter os bens patrimoniais - principalmente territorial -, e o prestígio social e político da família. Em sua maioria, os enlaces eram realizados entre consanguíneos, indivíduos portugueses e membros de importantes famílias da região. Ao optar por familiares, os pais privilegiavam a conservação da terra entre os parentes, evitando que os bens se dissipassem ao longo das gerações.

Importantes alianças familiares, econômicas e políticas foram formadas através dos matrimônios, ao casar suas filhas com homens com cargos militares, como sargento-mor, capitão, tenente e ofícios camarários, essas famílias além de fortuna obtinham prestígio, renome e distinção tão imprescindíveis em uma sociedade marcadamente excludente. Para que então esses promissores matrimônios se realizassem os genitores utilizaram de vantajosos dotes que atraíam propícios cônjuges.

\section{Dotes}

Dote significa etimologicamente os bens que a noiva (ou noivo) levava para o casamento. Sob a denominação "escritura de dote e arras", esse tipo de contrato estabelecia a separação de bens entre os cônjuges, conservando o que era oferecido para o matrimônio. Raros tanto em Portugal como no Brasil, este tipo de acordo constituía na promessa de que o marido ofereceria certa quantia à mulher para seu sustento. $\mathrm{O}$ contrato mais comum, tanto na Colônia quanto no Reino, era os casamentos concebidos por "carta ametade", no qual o consorte era meeiro dos bens do casal. Neste contexto, o dote representava a antecipação da herança que caberia aos cônjuges por falecimento de seus progenitores (BRÜGGER, 2007, p. 169). Em termos jurídicos, como ressalta Maria Beatriz Nizza da Silva, o dote equivalia ao que:

[...] impropriamente se chamam dotais
quaisquer bens doados à noiva, ainda
que dados para manter os encargos do
matrimônio, e que se chamem dote, se
ela os comunica com o marido; caso em
que não gozam dos privilégios dotais,
por isso que estes privilégios concedidos
somente para obviar que as mulheres

\footnotetext{
${ }^{1}$ Processo Matrimonial - Arquivo Eclesiástico da Arquidiocese de Mariana, de Antônio Alves Ferreira, do ano de 1728.
} 
não viessem a perder os seus dotes, ficando reduzidas à indigência (SILVA, 1984, p. 99).

A prática de dotar as filhas em vias de contrair matrimônio foi habitual tanto nas regiões brasileiras quanto portuguesas. O dote de acordo com o dicionarista Moraes e Silva equivaliam aos "bens, que se dão à pessoa, que se casa, para suster os encargos do estado" (BRÜGGER, 2007, p.170). De acordo com Maria Beatriz Nizza da Silva, o dote:

[...] em sentido amplo e dentro do sistema de meação, não significava apenas um adiantamento da legítima, mas também a soma de bens com que cada um dos contraentes entrava para o matrimônio, quer esses bens já tivessem sido herdados quer fossem adiantados pelos progenitores (SILVA, 1984, p. 101).

Nesse sentido, o dote preenchia alguns requisitos da sociabilidade da dádiva, pois o dar e receber implicava não apenas uma troca material, mas também simbólica. Dessa forma, ao tratar o casamento como um negócio de família em vez de uma escolha individual, podemos pensar uma noção de contrato social de maneira mais ampliada, diferente dos economistas liberais do final do século XVIII, considerando que neste ato de contrato nupcial não eram os indivíduos que se obrigavam mutuamente e sim uma coletividade, constituída pela família e seu grupo social, que trocavam e contratavam (ABRANTES, 2010).

A preocupação em conceder dote às mulheres para que se casassem foi objeto determinante entre os indivíduos coloniais. Antônio Pereira dos Santos, por exemplo, quando elaborou seu testamento deixa para a filha de sua prima Anna Pereira moradora na Vila do Conde (Portugal), $100 \$ 000$ (cem mil réis) para que fossem dados em dote para seu casamento. ${ }^{2}$ A preocupa- ção em dotar as mulheres e arranjar um bom pretendente era essencial, já que o casamento era entendido como um meio de 'proteção' e sobrevivência econômica da mulher, pois era da competência do marido zelar pela segurança da esposa e dos filhos, incluindo a administração dos bens do casal. Entre os pedidos e mesmo obrigações impostas a tutores, parentes, amigos ou curadores, estava o de 'arranjar marido'. Por essa razão, a mulher, desde que sua família tivesse boas condições econômicas, teria a certeza do dote e de um pretendente (SAMARA, 1986, p. 51-52).

Muriel Nazzari ao analisar a prática dotal na região de São Paulo, destaca que o dote era um requisito do casamento: uma questão de propriedade. E era concedido não só à filha ou ao marido, mas a ambos. Neste sentido, as filhas de famílias de posses jamais iam para o casamento de mãos abanando (NAZZARI, 2001, p.46). O dote, deste modo, como instituição fundamental do sistema colonial era objeto não só dos pais, mas também dos demais parentes (SILVA, 1984, p.103).

O estabelecimento de um jovem casal representava um momento decisivo na vida familial, para o qual contribuíram não apenas o pai da moça (como era de esperar), mas também outros parentes. Tudo se passa como se o clã familiar se reunisse para possibilitar a sobrevivência daqueles que saíam de casa de seus pais para começar nova vida (SILVA, 1984. p. 105-106).

Como destaca Carlos Almeida Prado Bacellar, não havia regras para a definição do montante doado às filhas e aos filhos. Os pais repassavam o que podiam e o que não podiam. "O dote serviria não somente para dar o primeiro empurrão na vida independente dos filhos, mas também para servir de atrativo para os pretendentes visados" (BACELLAR, 1997, p. 128).

\footnotetext{
${ }^{2}$ Inventário post-mortem do Acervo da Casa Setecentista de Mariana, $1^{\circ}$ ofício, Códice 8, Auto 324, 1764.
} 
$\mathrm{O}$ dote foi tão determinante na realização do casamento que no inventário de Ana dos Reis Pimentel, viúva de José Correa Florim e Cosme de Amorim Velloso ao se casar pela terceira vez com o Alferes Antônio Machado Cotta dota seu marido com uma escritura pública no valor de sua terça $871 \$ 893$ (oitocentos e setenta e um mil e oitocentos e noventa e três réis). Esse considerável valor possivelmente atrairia a atenção do futuro nubente, pois, embora viúva, Ana teria muito a oferecer ao novo cônjuge.

As mulheres viúvas contraiam esponsais em menor número que os homens, no entanto como ressalta Sheila de Castro Faria: "a mulher branca, com maior probabilidade de ser proprietária de bens e escravos, mantinha melhores condições de acesso a outro casamento, mesmo que tivesse filhos pequenos" (FARIA, 1998, p. 155). O que não foi o caso de Ana, ainda que viúva duas vezes, não tivera filhos com nenhum dos três maridos, o que provavelmente facilitou a obtenção de seu novo matrimônio.

A maioria dos genitores, como assegura Nazzari, se esforçava muito para conceder dotes às filhas, a tal ponto que muitas dessas mulheres chegaram a receber dotes que superavam abundantemente os bens que seus irmãos herdariam na partilha (NAZZARI, 2001, p. 47). Esse tipo de desigualdade foi frequente entre os indivíduos coloniais, embora a legislação portuguesa reconhecesse o procedimento de divisão igualitária entre os sucessores, podemos observar que alguns herdeiros eram privilegiados entre os demais. Em Guarapiranga, por exemplo, é possível discernir as regalias que as dotadas obtiveram em relação aos seus irmãos.

O dote foi um poderoso mecanismo de privilégio entre os filhos e funcionou como um importante elemento no estabelecimento de eficientes uniões matrimoniais, acordos políticos e redes familiares. Com vali- osos dotes os pais garantiam às filhas bons casamentos, já que para elas não havia outra possibilidade de se colocarem a não ser através dos esponsais, no entanto, este costume gerava desigualdade no espólio entre os herdeiros (DURÃES, 2004, p. 15).

Diferentemente do que anunciava as leis portuguesas, na colônia os bens familiares não foram, em sua maioria, divididos igualmente entre os sucessores, muitos foram os métodos empregados pelas famílias para que os bens não se dissipassem, privilegiando matrimônios que garantissem variados benefícios. Os casamentos, sacerdócio, imigração e colocação em importantes ofícios foram as situações que levaram os testadores a concederem "legado por conta da legítima" aos herdeiros, antecipando a herança a ser recebida e evitando conflitos entre o sucessor/ herdeiro e os não sucessores (DURÃES, 2002, p. 137). A lei permitia que os dotados voltassem ao "monte", "colando" os bens e recebendo a legítima final, no entanto, a partilha era feita somente em relação aos bens móveis e partíveis. Entretanto, entre os herdeiros dotados poucos foram os que entraram em "colação", já que usualmente os bens recebidos ultrapassavam o montante.

O inventário post-mortem de Antônio Luiz de Miranda expõe claramente o privilégio das filhas em relação aos demais filhos, ao se casarem, recebem montantes vultosos. Embora todos os filhos tenham sido agraciados com bens de valor, as três filhas que contraíram matrimônio obtiveram vantagens, já que com a antecipação daquilo que seria sua legítima elas puderam usufruir dos bens recebíveis anos antes dos outros herdeiros. As doações aos filhos, como é observado, eram esporádicas, o que sugere que era mais usual dotar as filhas do que favorecer os filhos com algum tipo de doação.

Ao elaborar seu inventário, Antônio que tivera oito filhos, doa quantias volumosas às três filhas que se 
casaram, embora tivesse agraciado os outros filhos com algum tipo de doação. Nas concessões podemos distinguir nitidamente o privilégio concedido às mulheres que casaram:

Maria das Neves que casou com Francisco Faria Seixas recebeu em dote onze escravos, um cavalo selado e enfreado, uma cama com seus reparos, uma colcha de damasco, várias colheres e garfos de prata, ouro lavrado tudo no valor de 8 mil cruzados $(3.200 \$ 000$ - três contos e duzentos mil réis) ; Florência ao se casar com o Capitão Antônio de Souza Ferreira recebeu em dote em ouro cinco mil cruzados $(2.000 \$ 000$ - dois contos de réis), um cavalo selado e enfreado, uma escrava por nome Josefa e uma crioula filha da mesma por nome Cristina e ouro lavrado. Anna Martins de Paiva ao se casar com Belchior de Azevedo Duarte foi dado em dote quatro escravos, três escravos, um cordão de ouro e uma crioula por nome Maria que foi dada a neta Anna (filha de Florência) no valor de $700 \$ 000$ (setecentos mil réis). Ao filho Salvador foi dado uma fazenda com seus pertences e um crioulinho no valor de 3 mil cruzados (1.200\$000 - um conto e duzentos mil réis); a Francisco quando foi trabalhar em uma lavra no Rio de Janeiro foi the entregue quatro escravos e a única filha solteira foi doado três escravos. $^{3}$

Ainda que Antônio tenha doado bens aos demais filhos, foram as filhas que se privilegiaram com os bens recebidos antes do exórdio da partilha. Com um monte-mor de 8:370\$861 (oito contos, trezentos e setenta mil e oitocentos e sessenta e um réis) e a terça no valor de 2:174\$948 (dois contos, cento e setenta e quatro mil e novecentos e quarenta e oito réis), seu espólio final se apresentava no total de 6:105\$913 (seis contos, cento e cinco e mil e novecentos e treze réis). A legítima de cada herdeiro, portanto foi de $885 \$ 130$ (oitocentos e oitenta e cinco mil e cento e trinta réis), valor muito inferior ao dote recebido pelas filhas. Cla- ramente houve um privilégio às filhas que se casaram $\mathrm{e}$ embora os filhos tenham recebido um quinhão da fortuna, o valor foi relevantemente inferior ao adquirido pelas mulheres.

Já os homens que decidiam seguir a vida eclesiástica foram os únicos a receberam quantias tão abundantes quanto os dotes recebidos pelas filhas. Como assegura Nazzari:

Os padres eram os únicos filhos a receber dos pais doações pre-mortem tão consideráveis quanto os dotes de suas irmãs. Os padres precisavam de bens em terras e indios que lhes proporcionassem um meio de vida, uma vez que a Coroa sustentava muitos poucos padres no Brasil Colonial (NAZZARI, 2001, p.50).

Muito embora todos os outros filhos homens também necessitassem desses bens para se estabelecerem independentemente, os clérigos eram os únicos indivíduos que não se casavam e tinham direito de receber o dote concedido às esposas (NAZZARI, 2001, p. 50). Como o caso de Antônio Luiz de Miranda que concedeu bens ao filho Salvador para que se ordenasse sacerdote. No testamento declara:

Ao filho Salvador the deu o patrimônio para se ordenar, a fazenda do Italumi e the deu mais um crioulinho por nome Antonio o qual ele criou e ficou para se paguem e a fazenda foi junto com os seus pertences roças e lavras velhas, casas e paiol e tudo no valor de 3 mil cruzados (1:200\$000 - um conto e duzentos mil réis). ${ }^{4}$

Essa prática era comum entre os habitantes da região de Guarapiranga. No inventário de Manoel Leitão de Almeida de 1787 foi legado aos filhos Joaquim com 19 anos e Martinho com 15 anos, cem mil réis a cada um para que pudessem se ordenar padres. Em seu

\footnotetext{
${ }^{3}$ Inventário post-mortem do Acervo da Casa Setecentista de Mariana, $1^{\circ}$ ofício, Códice 31, Auto 756, 1777.

${ }^{4}$ Inventário post-mortem do Acervo da Casa Setecentista de Mariana, $1^{\circ}$ ofício, Códice 31, Auto 756, 1777.
} 
testamento, Manoel declarou que para ordenar seu filho mais velho Bento Leitão de Almeida sacerdote lhe concedeu dois escravos Caetano Cabunda no valor de 100 $\$ 000$ (cem mil réis) e Domingos Crioulo de $80 \$ 000$ (oitenta mil réis), um corte de terras de plantar com margens no Rio Xopotó no valor de $300 \$ 000$ (trinta mil réis) e mais um cavalo selado e enfreado de $20 \$ 000$ (vinte mil réis). ${ }^{5}$ Todos esses bens garantiriam a Bento seu sustento e uma vida razoavelmente confortável. Um filho eclesiástico concedia a família e ao sujeito status perante a sociedade, além de conferir ao indivíduo um ofício e um quinhão farto da herança.

Contudo não eram apenas os filhos clérigos que recebiam dotes. Apesar de figurar destacadamente como uma prática destinada às filhas, os dotes também poderiam ser concedidos aos filhos. Como no caso de Thomas Ferreira Braga ${ }^{6}$ que ao elaborar seu inventário no ano de 1789 declara que doou ao filho José Vicente Ferreira ao se casar um escravo no valor de $100 \$ 000$ (cem mil réis), ao filho Custódio Ferreira Braga que também ao contrair esponsais recebeu um escravo no valor de $100 \$ 000$ (cem mil réis) e mais a quantia de $100 \$ 000$ (cem mil réis) em dinheiro e ainda ao filho Joaquim Ferreira Braga que recebeu um escravo no valor de $80 \$ 000$ (oitenta mil réis) ao contrair matrimônio.

Apesar do exemplo acima em Guarapiranga foram raros os casos em que os pais dotaram seus filhos quando se casavam ou por outros pretextos. Foram as mulheres que se privilegiaram em abundância com a concessão de bens recebidos antes do falecimento dos progenitores. O privilégio das mulheres, como destaca Nazzari, começava cedo em suas vidas, grande parte dos espólios ou doações eram concedidos em benefício de seus dotes, muitos anos antes de se casarem, e até mesmo durante a infância ou antes de nascerem (NAZZARI, 2001, p. 54). Era comum entre os genitores e parentes próximos deixarem em seu legado determinada quantia a uma jovem moça solteira para amparar o seu casamento ou ajudá-la em seu dote.

Foi através das uniões matrimoniais que uma família estabelecia seus laços sociais, econômicos e políticos e a escolha do genro poderia definir toda a estrutura familiar e angariar todo tipo de vantagem necessária a manutenção do grupo. Como afirma Tarcísio R. Botelho:

O matrimônio é um momento crucial dentro das estratégias de reprodução social. Ao estabelecer laços entre grupos familiares, ele torna-se o garantidor da perpetualidade de tais frutos ao mesmo tempo em que amplia as redes sociais dos indivíduos escolhidos. Em razão dessa sua enorme importância, as decisões em torno da escolha dos nubentes sempre recaíram sobre o grupo familiar mais amplo. Definir o cônjuge de um filho ou uma filha era uma tarefa decisiva para a família, e não podia ser deixado sob responsabilidade dos jovens. No cálculo matrimonial entravam diversas variáveis, ligadas sobretudo às possibilidades de manutenção do status quo ou de ascensão social do grupo (BOTELHO, 2004, p. 2).

A escolha dos genros passava por diversas demandas: a posição social de sua família, o posto que ocupava, a mercê concedida pela Coroa, o tipo de negócio que desenvolvia, os recursos que dispunha ou mesmo o simples fato de ser português e branco. Diferentes estratégias foram empregadas pelas famílias de posse ao determinar o consorte de suas filhas, até mesmo o volume dos bens concedidos. Nazzari afirma que a concessão de um dote vultuoso beneficiava a família:

\footnotetext{
${ }^{5}$ Inventário post-mortem do Acervo da Casa Setecentista de Mariana, $2^{\circ}$ ofício, Códice 75, Auto 1626, 1787.

${ }^{6}$ Inventário post-mortem do Acervo da Casa Setecentista de Mariana, $2^{\circ}$ ofício, Códice 136, Auto 2745, 1789.
} 
Um bom dote podia atrair sangue nobre, o que era importante levar em conta numa época em que a nobreza conferia muito mais status do que a riqueza. [...] $O$ status de nobre, mesmo que fosse apenas como "fidalgo", dava aos recémchegados a oportunidade de conseguir um excelente partido, ainda que eles fossem possuidores de poucos bens, ou de nenhum (NAZZARI, 2001, p. 69).

No inventário do Alferes João Gonçalves Vieira que concede dote a duas de suas filhas é aparente o privilégio concedido a uma delas. Dos seus nove filhos, seis deles mulheres, apenas a mais velha de 34 anos e uma das mais novas de 18 anos se encontravam casadas na ocasião da elaboração do inventário. Francisca Thereza casada com o Alferes Manoel da Silva Carreiro recebeu ao se casar quatro escravos a saber: Caetano Angola de 35 anos no valor de $120 \$ 000$ (cento e vinte mil réis), Manoel Angola de 30 anos no valor de 100 $\$ 000$ (cem mil réis), Domingos Angola de 25 anos no valor de $70 \$ 000$ (setenta mil réis), João Angola de 40 anos no valor de $40 \$ 000$ (quarenta mil réis). Ganhou ainda umas terras de cultura no córrego chamado "Os Três Tiras" com matas virgens e sem cultura alguma no valor de $140 \$ 000$ (cento e quarenta mil réis), onde reside, somando no total a importância de $470 \$ 000$ (quatrocentos e setenta mil réis). Já Maria Joaquina, uma das caçulas recebeu em dote ao se casar com Joaquim José Moreira dois escravos, Raiumundo Crioulo de 10 anos no preço de $70 \$ 000$ (setenta mil réis) e Felizardo Crioulo de 12 anos também no valor de $70 \$ 000$ (setenta mil réis), no total $140 \$ 000$ (cento e quarenta mil réis). ${ }^{7}$ As vantagens angariadas por Francisca são iminentes, no entanto, quais seriam os motivos do genitor ao conceder tamanho privilégio à filha mais velha?
O primeiro elemento que poderíamos destacar seria a progenitura, já que como primeira filha a se casar Francisca obteria vantagens e privilégios que as demais não alcançariam. De acordo com Muriel Nazzari ao pesquisar a prática de dotes nas famílias paulistas do século XVIII, grande parte delas concederam o dote mais generoso à filha mais velha (NAZZARI, 2001, p. 117). Ao analisar a região de Guarapiranga é possível observar que essa prática também era habitual, $51,4 \%$ das mulheres mais velhas recebiam dotes maiores do que suas irmãs. Para Nazzari, as famílias que doaram dotes superiores às primogênitas em São Paulo o fizeram por possuírem patrimônios menores:

Pode-se especular que ou concederam a
suas primeiras filhas dotes tão generosos
por terem expectativas de uma crescente
prosperidade que não se materializou, ou
o dote grande foi concedido antes que
diminuíssem os bens da família, ou,
ainda, uma familia em dificuldade optava
deliberadamente por conceder um dote
de bom tamanho para manter seus status
mediante o bom casamento de pelo
menos uma das filhas (NAZZARI,
2001, p. 118).

Na região de Guarapiranga o monte-mor dos indivíduos que dotaram suas filhas mais velhas não constituíram, em larga escala, num montante inferior. Ainda que a freguesia não apresentasse inventariados com riquezas volumosas, esses genitores apresentavam uma fortuna que variava de 1:102\$812 (um conto, cento e dois mil e oitocentos e doze réis) a 17:623\$000 (dezessete contos, seiscentos e vinte e três mil réis), permacendo grande parte deles entre a quantia de 3 a 9 contos de réis. ${ }^{8}$ Possivelmente as filhas mais velhas, por esta condição, encontravam-se disponíveis ao contato

\footnotetext{
${ }^{7}$ Inventário post-mortem do Acervo da Casa Setecentista de Mariana, $1^{\circ}$ ofício, Códice 79, Auto 1688, 1787.

${ }^{8}$ Inventários post-mortem do Acervo da Casa Setecentista de Mariana.
} 
com os homens mais conceituados da região e, portanto, realizavam convenientes uniões matrimoniais.

Como anteriormente ressaltado, possivelmente o simples fato de ser português favorecia no processo de escolha do genro, de acordo com Nazzari:

A fidalguia e o status disso resultante, que alguns genros portugueses trouxeram para dentro das famílias de suas esposas, podem ajudar a explicar por que alguns genitores favoreceram algumas das filhas não só em relação a seus filhos homens, mas também a outras filhas (2001, p. 70).

Deste modo, o renome do genro consistiria também em outro artifício empregado pelas famílias de elite ao privilegiarem suas filhas mais velhas. No inventário de Antônio Alves Ferreira, anteriormente citado, o mesmo teria concedido à filha mais velha Maria Ferreira da Anunciação ao se casar com o Tenente João Rodrigues dos Santos: o valor de 105.000 cruzados (42:000\$000 - quarenta e dois contos de réis) em dinheiro, nove escravos no valor total de 822 oitavas de ouro ${ }^{9}(986 \$ 400$ - novecentos e oitenta e seis mil e quatrocentos réis), um sítio de roça de capoeiras com vinte e cinco alqueires de planta e restingas de matas virgens no corrégo do Angu no valor de 64 oitavas de ouro $(76 \$ 800$ - setenta e seis mil e oitocentos réis) e mais um móvel de jacarandá e uma mesa, os dois com preço de 11 oitavas de ouro (13\$200 - treze mil e duzentos réis), no valor total e admirável de 43:076\$400 (quarenta e três contos e setenta e seis mil e quatrocentos réis). ${ }^{10}$ João Rodrigues era um homem de renome entre os membros da freguesia. De acordo com Carla Maria Carvalho de Almeida, que analisou os homens considerados os mais ricos de Minas Gerais, João Rodrigues dos Santos aparece na listagem, classificado como mineiro:
Português de nascimento, provavelmente da cidade de Lisboa, João Rodrigues ainda muito jovem se tornava Cavaleiro Professo da Ordem de Cisto, o que lhe garantia privilégios e distinção além de lhe conferir "alguma nobreza". (...) Veio para as Minas já provido no cargo de inquiridor, distribuidor e contador da Vila de São João Del Rei pelo período de um ano (ALMEIDA, 2010, p.71-73).

Esses títulos conferidos a João teriam lhe transformando em um pretende visado pela elite de Guarapiranga. Deste modo, para que a união matrimonial entre João e Maria fosse realizada foi preciso que o casamento apresentasse vantagens prodigiosas a ambos. Se por um lado, João receberia em dote por se casar com a filha de Antônio um quantia suntuosa, por outro, o patriarca realizaria um consórcio lucrativo no qual agregaria benefícios sociais e econômicos para a sua família. Reconhecidos como senhores de prestígio na região, Antônio e João provavelmente eram relacionados pela efetivação de negócios anteriores, o que teria facilitado e ampliado as possibilidades da realização do consórcio.

Com a promessa de bons dotes, as famílias obtinham influência no arranjo dos casamentos e definiam os genros de acordo com as vantagens que fossem estabelecidas.

Assim, o casamento era não tanto um assunto pessoal quanto era um assunto de família, e isso favorecia a família de muitos modos. O casamento de filhos, ou filhas, dava continuidade às linhagens dos dois genitores porque, no Brasil como em Portugal, a linhagem se transmitia tanto pelos homens como pelas mulheres. Além disso, o casamento de um filho dava a sua família como um todo uma aliança como a família da noiva, acrescida de uma nova unidade produtiva, instalada, em sua maior parte, como o dote da noiva. Inversamente, pelo casamento de uma

\footnotetext{
${ }^{9}$ No período colonial uma oitava de ouro equivalia a $1 \$ 200$ (mil e duzentos réis).

${ }^{10}$ Inventário post-mortem do Acervo da Casa Setecentista de Mariana, $1^{\circ}$ ofício, Códice 36, Auto 843, 1750.
} 
filha, a família ganhava um novo sócio, que podia colaborar para a expansão do empreendimento familiar (NAZZARI, 2001, p. 66).

Ao analisar o caso de João Rodrigues dos Santos e outros casos apontados entedemos que para a realização de um matrimônio era necessário a elaboração de uma rede de componentes e artifícios que ultrapassam em muito a simples vontade de união do casal. A família, os parentes e mesmo a sociedade como um todo consentiam e organizavam a ligação entre os indivíduos. Distintos mecanismos foram utilizados pelos progenitores no intuito de efetivar um casamento satisfatório à família. $\mathrm{O}$ dote, por exemplo, se apresentava como um atrativo ao candidato visado e distinguia os casais que se privilegiaram com os bens recebidos. Como alega Bacellar: "dotar as filhas era um dos meios encontrados pela elite para manter e reproduzir seu status social e para preservar e concentrar as fortunas familiares" (BACELLAR, 1997, p. 135).

O dote, portanto, se compunha como um poderoso mecanismo de privilégio de determinados filhos e funcionava como um importante elemento no estabelecimento de eficientes uniões matrimoniais. Foi também através da concessão de dotes e das diferenças exorbitantes entre os bens recebidos pelas filhas dotadas que identificamos que em Guarapiranga, assim como outras regiões da colônia, o sistema igualitário de divisão de heranças não imperava. As regalias foram práticas frequentes entre os indivíduos, que lobrigavam nos casamentos e nas alianças familiares um canal eficiente de manter e ampliar o poder social, econômico e político.

O privilégio conferido através dos dotes, algumas vezes, foram atenuados quando os bens eram trazidos à "colação" na partilha da herança e elaboração do inventário. A prática da colação era feita tão somente no sistema de meação, de acordo com as Ordenações Filipinas nesse preceito:
[...] o doado somente devia conferir a metade do que lhe fora dado, por morte de um dos cônjuges, e a outra metade por morte do outro, querendo entrar na herança do que faleceu, mas se o herdeiro, a quem tivesse sido feita a doação por ocasião do casamento, não quisesse entrar na herança, não seria obrigado a tornar a seus irmãos o que lhe fora dado, a menos que o dote excedesse a sua legítima e terça, porque só então seria obrigado a entregar o excesso. $O$ objetivo da colação era, portanto, manter a igualdade entre todos os filhos na herança, evitando-se assim que por ocasião do casamento alguns fossem beneficiados. Mesmo que os dotes tivessem sido desiguais, a igualdade era restabelecida no momento do inventário e das partilhas (SILVA, 1984, p. 102).

Com o objetivo de restabelecer a igualdade entre os herdeiros, a colação era empregada no intuito de evitar o favorecimento de um filho em detrimento do outro. No entanto, diversas lacunas nas Ordenações possibilitavam que a igualdade não fosse estabelecida, como ressaltou Maria Beatriz Nizza da Silva, assim os filhos não seriam obrigados a trazer à colação os bens recebidos. Apesar disso, de acordo com Brugger, as Ordenações ao avaliar se o dote ou as doações eram superiores a legítima, decretavam que:

$$
\begin{aligned}
& \text { [...] se há de olhar a valia dos bens do } \\
& \text { que os deu, ou prometeu em casamento } \\
& \text { ao tempo, que a fez, ou ao tempo de sua } \\
& \text { morte, qual escolher o donatário. E esta } \\
& \text { escolha será somente nas doações dadas } \\
& \text { em casamento: porque nas outras } \\
& \text { doações, que se fizerem aos filhos, se } \\
& \text { olhará o que os bens do doador valerem } \\
& \text { ao tempo de sua morte (BRÜGGER, } \\
& \text { 2007, p. 171). }
\end{aligned}
$$

Nessas regras é perceptível o favorecimento do dote em relação às demais doações, talvez por reconhecer o relevo das alianças matrimoniais e das 
vantagens agregadas à efetivação do casamento (BRÜGGER, 2007, p. 171).

O dote, quando descrito no inventário, localizavase logo após o rol dos bens, exposto como declaração, ou nas doações alegadas no testamento. Quando esses bens se apresentaram superiores à legítima, as filhas casadas e seus maridos não traziam seus bens à colação e abriam mão da herança. Casos como estes foram frequentes entre os indivíduos na freguesia de Guarapiranga: Antônia Nunes de Assunção viúva de Antônio Dias dos Anjos dotou sua filha Maria Dias ao se casar com José Ribeiro de Castro Guimarães em 240 $\$ 000$ (duzentos e quarenta mil réis) em ouro e Anna crioula avaliada em $60 \$ 000$ (sessenta mil réis), no total o casal recebeu $300 \$ 000$ (trezentos mil réis) valor superior à legítima herdada por cada filho que foi de $209 \$ 475$ (duzentos e nove mil, quatrocentos e setenta e cinco réis). Maria e José se abstêm da herança em favor do dote. Episódios como estes foram habituais, vários casais desistiram de receber o valor da legítima para conservar os benefícios embolsados por ocasião da realização do casamento.

Alguns casais decidiram entrar em colação com os bens dotais, entre eles Fabiano Martins Moreira e Antonia Alvarenga, filha do Capitão-Mor Manoel Alves da Costa e Felipha Alvarenga. Os bens recebidos por Antonia foram uma escrava Joana Mina de 200 $\$ 000$ (vinte mil réis), 300\$000 (trinta mil réis) em dinheiro, um cordão de ouro no valor de $360 \$ 000$ (trinta e seis mil réis), um brinco de ouro no valor de 19 $\$ 200$ (dezenove mil e duzentos réis) e $56 \$ 700$ (cinquenta e seis mil e setecentos réis) em dinheiro, no total $935 \$ 900$ (novecentos e trinta e cinco mil e novecentos réis). No inventário foi colado na partilha o meio-dote do casal, 467\$950 (quatrocentos e sessenta e sete mil e novecentos e cinquenta réis); a cada herdeiro foi conferido o valor de $354 \$ 214$ (trezentos e cinquenta e quatro mil e duzentos e catorze réis) e ainda ficou adjudicado a Antonia todo o valor da terça, 634\$639 (seiscentos e trinta e quatro mil e seiscentos e trinta e nove réis). ${ }^{11} \mathrm{O}$ que observamos é que mesmo que os dotados, de acordo com as Ordenações Filipinas, fossem obrigados a entrar na herança, para evitar danos aos demais sucessores, a desigualdade na distribuição dos bens era evidente. De acordo com Muriel Nazzari:

No século XVII, os patriarcas e suas
esposas favoreciam algumas ou todas as
filhas, concedendo-lhes dotes muito
maiores do que a ulterior legitima e
essas filhas casadas abriam mão da
herança. Apesar de permitir que os
herdeiros declinassem da herança, as
Ordenações limitavam o direito dos
patriarcas ou suas esposas de favorecer
um dos filhos em relação aos demais,
mediante dote ou doação. Se o dote ou
doação tivesse sido maior do que a
legítima adicionada à terça, mesmo que
o herdeiro declinasse da herança, seria
obrigado a devolver a diferença aos
demais herdeiros. o pressuposto
subjacente neste caso é que um genitor
tinha o direito de dispor somente de sua
terça em favor de um filho. Um genitor
não devia favorecer nenhum dos filhos
em detrimento dos demais (2001, p.
124).

Com os exemplos descritos o que observamos é que o dote foi efetivamente um influente mecanismo de privilégio de determinados filhos. Era através da concessão de dotes e dos bens oferecidos ao pretendente que a família conseguiria ampliar e manter suas alianças familiares e assim, expandir sua rede clientelar, de poder econômico, político e social.

Os bens que compunham o dote faziam diferença determinante no momento da união matrimonial. Como principal benefício no momento de dotar os filhos, o escravo foi decisivamente o bem mais ofertado pelos

\footnotetext{
${ }^{11}$ Inventário post-mortem do Acervo da Casa Setecentista de Mariana, 2º ofício, Códice 18, Auto 493, 1738.
} 
progenitores. De acordo com Carlos Almeida Prado Bacellar:

O escravo era talvez a forma mais natural, prática e valorizada, dentro dos quadros do sistema, de se apoiar o esforço do filho ou do genro que buscava se estabelecer com sua recém- formada familia. Além de representar uma respeitável reserva de capital, o escravo apresentava a vantagem de permitir qualquer espécie de deslocamento geográfico por parte de seu novo proprietário, conforme suas necessidades (1997, p. 134).

Em Guarapiranga não foi diferente, a maioria dos genitores doavam principalmente aos seus filhos e filhas mão de obra escrava. No entanto, não é possível presumir que nesta região a doação do escravo constituíria em uma prática recorrente para a aquisição de status social. Por ser esta uma região marcada por atividades agropecuárias, que giravam em torno da posse de terras e escravos, a escravidão não serviria apenas como um fator de diferenciação social, mas também de manuntenção econômica e familiar.

Com plantéis de escravos relativamente pequenos, os proprietários de Guarapiranga avaliavam seus cativos como produto determinante no montante da riqueza. Era comum, doar em dote, escravos que possuíssem certa especialização, como mestre-deaçúcar, carpinteiro ou carreiro (FARIA, 1998, p. 192), desta forma, o pai concedia ao novo casal mão de obra que auxiliasse na montagem e no funcionamento de novas unidades produtivas.

Maria Beatriz Nizza da Silva encontrou o mesmo padrão para a região de São Paulo por ela pesquisada. Os principais bens concedidos foram:

Bens de raiz, sobretudo, casas ou sitios, peças do gentio da terra, gado, cavalgaduras, instrumentos agrícolas ou objetos como caixas, certamente para guardar a roupa de casas e as peças de vestuário, frequentemente doados, mobiliário, louça, jóias e mesmo mantimentos. $O$ elementos mais importante no dote, neste periodo, era indiscutivalemente o gentio da terra, que muitas vezes aparece sozinho como dotação matrimonial, sem quaisquer outros bens (SILVA, 1984, p. 106).

Na pesquisa realizada por Muriel Nazzari ela afirma que os dotes concedidos em São Paulo se diferenciavam entre os que continham meios de produção e meios de consumo. Terras agrícolas, ferramentas, maquinaria, gado e mulas eram considerados como meios de produção. Já casa, enxoval de noiva e joias eram meios de consumo, que geralmente eram vendidos para obtenção de dinheiro. Os escravos eram classificados como meio de produção ou como facilitadores do consumo destes (NAZZARI, 2001, p. 58-59).

$\mathrm{Na}$ freguesia de Guarapiranga, os escravos seguidos do ouro e dinheiro foram abundantemente os bens mais favorecidos no processo de concessão dotal. A existência de atividades mineradoras na região e a importância do ouro ainda nesse período fizeram com que o ouro estivesse entre os primeiros bens doados às filhas que se casavam. Considerados como meios de produção foram os escravos, especialmente, que possibilitaram aos indivíduos dar início e manter uma nova unidade produtiva.

O emprego indiscriminado da mão de obra escrava foi marca irrefutável na sociedade colonial. Embora a escravidão seja atributo que distinguia a América Portuguesa do Antigo Regime Europeu podemos afirmar que a Colônia apresentou peculiaridades marcadas por uma nítida e alargada diferenciação social, típicas das sociedades de Antigo Regime: uma sociedade hierarquizada e altamente excludente. Neste sentido, como observa Hebe Mattos, a escravidão se tornaria a condição básica para a 
constituição de uma sociedade católica, na qual se assentavam as características fundamentais de uma sociedade de Antigo Regime em que prevaleciam traços que legitimavam e naturalizavam as desigualdades e as hierarquias sociais (MATTOS, 2001, p. 143). Deste modo é equivocado considerar o escravismo como deturpação aos valores da cristandade, já que era habitual construir justificativas religiosas para expandir a ordem econômica e social baseado no cativeiro de gentios e negros na América e na África.

Nas palavras de Mattos:

[...] apesar de as diferenças de cor e de características fisicas reforçarem as marcas hierárquicas no processo de expansão da escravidão moderna, elas não foram realmente necessárias para justificar a existência da escravidão. Afirmar que a legitimação da escravidão moderna não se fez em bases raciais não implica, entretanto, considerar que estigmas e distinções com base na ascendência deixassem de estar presentes nas sociedades do Antigo Regime e, em especial, no Império Português (2001, p. 148).

$\mathrm{O}$ cativeiro de africanos esteve intrinsecamente ligado à sociedade colonial, inclusive no costume de dotar suas filhas prestes a se casar, como observamos ao longo do trabalho. A quantidade de escravos descritos no rol dos bens determinava a prosperidade de um indivíduo, assim como a abundância de cativos que seria possível concederem em dote.

De todos os inventários catalogados o que observamos é que mais de cem famílias possuíam um total entre um a vinte escravos e apenas trinta e três delas eram senhores de vinte escravos ou mais. Esse índice corrobora a concepção de que nesta freguesia as propriedades, em sua maioria, foram de pequeno porte e destinavam a mão de obra cativa à manutenção e ampliação das atividades produtivas, como a agropecuária e mineração paralelamente ao uso da força de trabalho familiar.

Em relação a outros meios de produção, a terra raramente aparecia nas dotações. Dentre os vinte e dois pais que concederam dotes aos seus filhos, apenas quatro deles se preocuparam em incluir terras entre os bens. De acordo com Muriel Nazzari, dotar as filhas com terras:

\section{[...] além de garantir que a filha e o genro morassem perto, dar-lhes terras no dote tinha outra vantagem para a família dela. Uma vez que a sesmaria exigia que a terra fosse cultivada no prazo de três anos, para a posse ser mantida, dotar uma filha com terras recebidas como sesmaria fortalecia o domínio da família sobre aquela terra (2001, p. 68).}

Manoel Leitão de Almeida que ao casar sua filha Marianna dos Santos com Domingos de Oliveira Leal lhe concedeu em dote quatro escravos mais uma sesmaria por completar nas margens do Rio Xopotó. ${ }^{12}$ Ao doar a sesmaria à filha, Manoel de certa forma constituía maior controle sobre o estabelecimento do novo casal.

Cabe destacar ainda que, a doação de dinheiro nos bens dotais em Guarapiranga foi expressivamente vultosa. Como destaca Brugger, "sem dúvida, este tipo de concessão permitia aos dotados maior liberdade, no sentido de sua aplicação" (BRÜGGER, 2007, p. 181). Outro item predominante entre os dotes do século XVII e XVIII na região de São Paulo, como enfatiza Nazzari, foi o enxoval, componente que não foi frequente entre os dotes em Guarapiranga. De acordo com a autora estavam inclusos nesta categoria vestimentas, ornamentos, móveis e trastes de casa.

\footnotetext{
${ }^{12}$ Inventário post-mortem do Acervo da Casa Setecentista de Mariana, $2^{\circ}$ ofício, Códice 75, Auto 1626, 1787.
} 
Ainda que existissem algumas diferenças entre a prática dotal de São Paulo comparada à Guarapiranga, podemos enfatizar que tais diversidades não separam as duas regiões. A distinção principal se encontra no recorte cronológico empregado por Nazzari, no qual foi possível abarcar séculos não analisados nesta pesquisa.

\section{Conclusão}

Analisando os inventários e a concessão de dotes dessa elite, que denominamos "econômica", podemos afirmar que a prática de dotação em Guarapiranga no século XVIII foi um mecanismo que permitia às filhas acesso precoce à herança e admitia o privilégio das mesmas em detrimento aos irmãos. Aos filhos homens, não dotados, restava tão- somente aguardar o falecimento dos pais para ter acesso ao espólio. Mesmo os filhos que embolsaram benefícios em vida dos pais, nunca chegaram a recebê-los na mesma proporção e qualidade que o dote atribuído as suas irmãs. Foi para garantir a consecução de casamentos vantajosos para a ascensão social e econômica para toda a família que os pais optavam por oferecer regalias para as filhas mulheres, selando vantajosas alianças familiares e matrimoniais.

\section{Referências bibliográficas}

ABRANTES, Elizabeth Sousa. "Dote é a moça educada": mulher, dote e instrução em São Luís na Primeira República. Tese apresentada ao Programa de Pós-Graduação em História da Universidade Federal Fluminense. Niterói, 2001.

ALMEIDA, Carla Maria Carvalho de. Uma nobreza da terra com projeto imperial: Maximiliano de Oliveira Leite e seus aparentados. In: FRAGOSO, João Luís Ribeiro; ALMEIDA, Carla Maria Carvalho de.; SAMPAIO, Antônio Carlos Jucá de (orgs). Conquistadores e Negociantes: história de elites no Antigo Regime nos trópicos. América lusa, séculos XVI a XVIII. Rio de Janeiro: Civilização Brasileira, 2007.

ALMEIDA, Carla Maria Carvalho de. Ricos e Pobres em Minas Gerais: produção e hierarquização social no mundo colônia, 1750 - 1822. Belo Horizonte, MG: Argvmentvm, 2010.

AMORIM, Maria Noberta; DURÃES, Margarida \& FERREIRA, Antero. Bases de dados genealógicos e História da Família em Portugal - Análises comparativas (do Antigo Regime à Contemporaneidade), La História de la Família em la Península Ibérica (ss. XVI - XIX), Balance y Perspectivas. Homenage a Peter Laslett, UCLM, Albacete, 2003.

BACELLAR, Carlos Almeida Prado. Os senhores da terra. Famílias e sistema sucessório entre os senhores de engenho do Oeste Paulista, 1765- 1885. Campinas: Centro de Memória da Unicamp, 1997.

BOTELHO, Tarcísio Rodrigues. População e nação no Brasil do Século XIX. São Paulo: Tese de Doutoramento, USP, 1998.

DURÃES. Margarida. Qualidade de vida e sobrevivência econômica da família camponesa minhota: o papel das herdeiras (séculos XVIII e XIX). Cadernos do Nordeste, vol 17, (1-2), 2002.

. Estratégias de sobrevivência econômica nas famílias camponesas minhotas: padrões hereditários (séculos

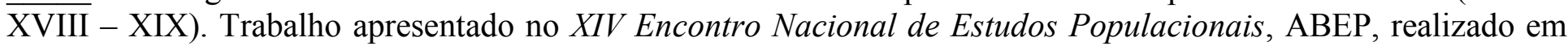
Caxambú -MG - Brasil, de 20 - 24 de Setembro de 2004.

FARIA, Sheila de Castro. A Colônia em Movimento: Fortuna e Família no Cotidiano Colonial. Rio de Janeiro: Nova Fronteira, 1998.

HESPANHA, António Manuel. Depois do Leviathan. Almanack Brasiliense. São Paulo, n5, maio de 2007. 
GOUVÊA, Maria de Fátima; FRAGOSO, João. Desenhando perspectivas e ampliando abordagens - do Antigo Regime nos Trópicos ao Trama das Redes". In: FRAGOSO, João; GOUVÊA, Maria de Fátima. (orgs). Na trama das redes: política e negócios no império português, séculos XVI -XVIII. Rio de Janeiro: Civilização Brasileira, 2010 .

MACHADO, Cacilda. Casamento e Desigualdade Jurídica. Primeiras notas de um estudo em uma área da região paulista no período colonial. Trabalho apresentado no XIII Encontro da Associação Brasileira de Estudos Populacionais, realizado em Ouro Preto, Minas Gerais, de 4 a 8 de novembro de 2002.

. A trama das vontades: negros, pardos e brancos na produção da hierarquia social do Brasil escravista. Rio de Janeiro: Apicuri, 2008.

MATTOS, Hebe Maria. A escravidão moderna nos quadros do Império Português: o Antigo Regime em perspectiva atlântica. In: BICALHO, Maria Fernanda; FRAGOSO, João e GOUVÊA, Maria de Fátima (orgs). O Antigo Regime nos Trópicos: a dinâmica imperial portuguesa (séculos XVI - XVIII). Rio de Janeiro: Civilização Brasileira, 2001.

NAZZARI, Muriel. O Desaparecimento do Dote: mulheres, famílias e mudança social em São Paulo, Brasil, 1600 - 1900. Trad. Lólio Lourenço de Oliveira. São Paulo: Companhia das Letras, 2001.

ROWLAND, Robert. População, família, sociedade: Portugal, séculos XIX-XX. Oeiras: Celta, 1997.

SCOTT, Ana Silvia Volpi. Famílias, Formas de União e Reprodução Social no Noroeste Português (Séculos XVIII e XIX). ed. 6. Guimarães: Editora NEPS - Universidade do Minho, 1999.

SILVA, Maria Beatriz Nizza da. Sistema de Casamento no Brasil Colonial. São Paulo: T. A. Queiroz: Ed. da Universidade de São Paulo, 1984.

Submissão: $30 / 09 / 2015$

Aceite: $20 / 06 / 2016$ 